\title{
The K-T boundary in Brazilian marginal sedimentary basins and related spherules
}

\author{
Gilberto Athayde Albertão, ${ }^{1 *}$ Alexandre de Azevedo Grassi, ${ }^{2}$ François Marini, ${ }^{3}$ \\ PAUlo Pereira Martins Jr. ${ }^{4}$ and Luiz Fernando DE Ros ${ }^{5}$ \\ ${ }^{1}$ PETROBRAS (UNBC/ST/CER), Av. Elias Agostinho 665, Imbetiba, Macaé, 27913-350, RJ, Brasil \\ ${ }^{2}$ PETROBRAS (UNEXP/ATEX/C-ES/PC), Av. Chile, Rio de Janeiro, RJ, Brasil \\ ${ }^{3}$ ENSG (Ecole Nationale Supérieure de Géologie), BP 40, 54501Vandoeuvre-les-Nancy CEDEX, and \\ CRPG-CNRS (Centre de Recherches Pétrographiques et Géochimiques), BP 20, 54501 Vandoeuvre-les-Nancy CEDEX, France \\ ${ }^{4}$ CETEC, Av. José Cândido da Silveira 2000, Horto, 31170-000, Belo Horizonte, MG, and \\ UFOP (Escola de Minas - DEGEO), Ouro Preto, 34500-000, MG, Brasil \\ ${ }^{5}$ UFRGS (Instituto de Geociências), Av. Bento Gonçalves 9500, Porto Alegre, RS, Brasil
}

(Received January 20, 2001; Accepted July 24, 2003)

\begin{abstract}
During the last 10 years some important results have been reached after extensive research performed on some Brazilian basins relating to the Cretaceous-Tertiary Boundary (KTB) matter. This paper presents some of these results mainly focused on the spherule content of the sediments.

The preliminary analysis carried out without strong constraints have not revealed any distinguishing and typical characteristics known for the KTB. These geochemical analysis were performed on ditch samples, from subsurface data, submitted to statistical tests such as factor and discriminant analysis. The result of the factor analysis indicated general trends in the concentration of chemical elements while the discriminant analysis showed a very clear discontinuity of the chemical data between the Cretaceous and Tertiary periods.

The first occurrence of spherules was found in sediments from the KTB of Pernambuco-Paraíba Basin (PE-PB). Despite other impact-derived characteristics present in this sedimentary section these spherules do not show any direct evidence of an impact origin. On the other hand, the study of microspherules recovered from a drilling core of Campos Basin has probably revealed the first documented occurrence of tektites in South America.
\end{abstract}

Keywords: K-T boundary, Brazilian marginal sedimentary basins, impact microspherules, geochemical profiles, iridium-anomaly

\section{INTRODUCTION}

Despite the initial lack of specific studies for identification of a complete section with a Cretaceous-Tertiary transition in the Brazilian sedimentary basins at the beginning of the 90's, some areas (outcrop data) and drilling wells (subsurface data) were selected on the basis of PETROBRAS-Petróleo Brasileiro S.A.—data and more systematically studied (Albertão, 1993). Drilling wells from the Campos (RJ), Espírito Santo (ES) and SergipeAlagoas (SE-AL) Basins and some outcrops from the Pernambuco-Paraíba Basin (PE-PB Basin) were selected (Fig. 1).

Three different main stages of these studies may be identified at the present. In the first one, a very general

*Corresponding author (e-mail: albertao@petrobras.com.br)

This paper was presented at Tecos Meeting in 1999.

Copyright (C) 2004 by The Geochemical Society of Japan. approach was attained from the first investigations. It was possible to select 5 wells, which contained presumably continuous Cretaceous-Tertiary transitions. These wells, 2 from RJ Basin (called here RJ-1 and RJ-2), 2 from ES Basin (ES-1 and ES-2) and 1 from SE-AL Basin (SE-1), present only composed ditch samples, without cores or lateral samples. For these wells, INAA (Instrumental Neutronic Activation Analysis) was performed by the Los Alamos National Laboratory with the objective of determining the Ir-content. Although an Ir-anomaly was not observed in these samples a by-product was the determination of concentrations for other 45 elements. Accuracy obtained from these concentration analyses varied in general from 5 to 8 percent.

The second stage is related to the characterization of the PE-PB Basin outcrops as one of the most complete KTB sections in South America (Albertão, 1993). There it was possible to determine the presence of a major biotic extinction, Ir and total organic carbon (TOC) anomalies, a possible tsunamiite, microspherules, and possible shocked quartz grains (Albertão et al., 1994; Albertão and 


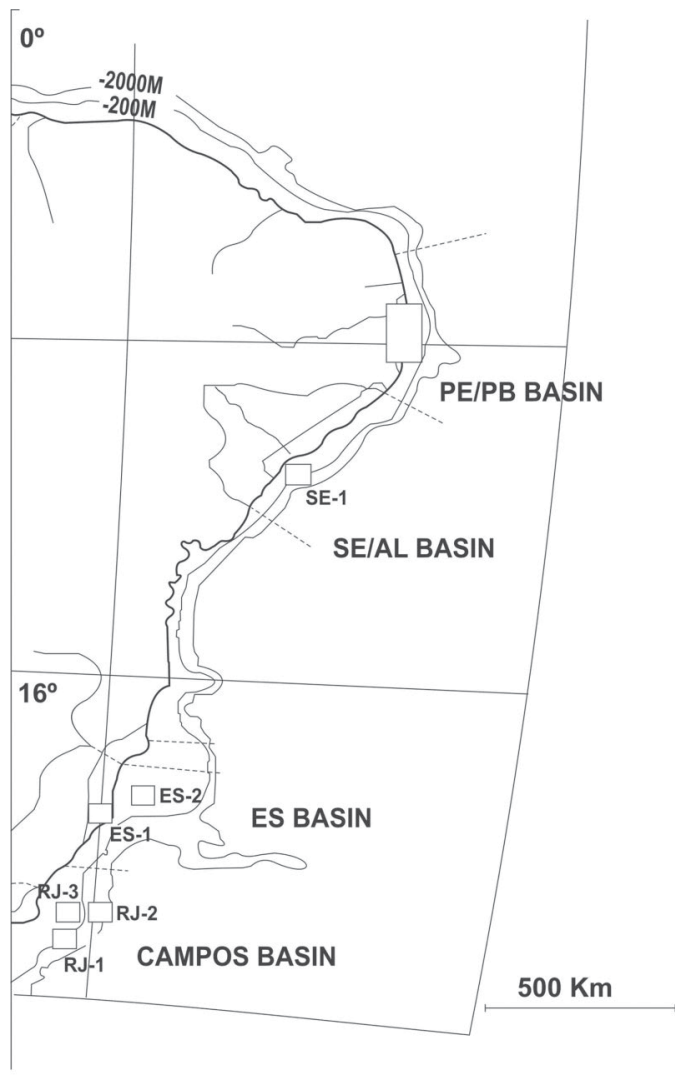

Fig. 1. Localization of the studied areas: drilling wells from Campos Basin in Rio de Janeiro shelf (wells RJ-1, RJ-2 and RJ-3), Espírito Santo (ES) Basin (wells ES-1 and ES-2) and Sergipe-Alagoas (SE-AL) Basin (well SE-1), and outcrops from Pernambuco-Paraíba (PE-PB) Basin.

Martins Jr., 1996a, b). The microspherules present near and at the KTB have been more extensively studied under the scope of the IGCP 384 Project (Albertão, 1997; Delício et al., 1998; Marini et al., 1998, 2000).

More recently, two cores recovered from drilling wells in the RJ Basin were characterized as presenting continuous sequences across the KTB (Grassi, 2000). One of them (RJ-3) contains a conspicuous marker-bed characterized by the presence of microspherules and an Ir-anomaly at its top. The microspherules exhibit features that indicate their impact origin; this is considered the third stage of the KTB studies in Brazilian basins.

\section{SAMPling AND ANALYTICAL Methods: RJ, ES AND SE-AL BASINS}

\section{Geochemical profile}

Geochemical profiling is a useful tool for stratigraphic correlation and environmental analysis of the stratigraphic record. With this purpose some of the Brazilian coastal basins were submitted for geochemical analysis in order to determine the differences in the depositional environments between the Upper Cretaceous and Lower Tertiary (K-T) as far as the quality of the sampling would permit. The KTB in each well was determined through micropaleontological analysis (PETROBRAS data base); however due to the very nature of such data (ditch samples), the KTB positioning cannot be considered as an exact one.

Three coastal basins were selected: RJ, ES and SEAL Basins (Albertão, 1993; Albertão and Martins Jr., 1996c). Geochemical analysis comprised 46 elements, and 15 of them were considered of good quality for the analytical description. The criteria for selecting them were the results of a factor analysis combined with their chemical affinities and relative abundance. The following elements were selected for being considered in this paper: $\mathrm{K}, \mathrm{Mg}, \mathrm{Na}, \mathrm{Al}, \mathrm{Ca}, \mathrm{Fe}, \mathrm{Ce}$, Th and $\mathrm{Cr}$.

The depositional environments of these coastal basins are generally recognized as complex systems with terrestrial clastics submitted to a highly intensive diagenesis. Geochemical determination of major and trace elements will thus represent all these factors together. They can be taken at their face value for a bulk comparison between different strata and wells. A more detailed environmental perspective would demand specific studies in other wells with continuous sampling for the K-T transition.

It would have been desirable to perform a chemical balance, but that would require other data, such as Si and $\mathrm{P}$ (and other major element) concentrations not available from neutron analysis.

\section{Geochemical profile evaluation}

Concentrations of chemical elements were studied according to depth. Statistical parameters are: Pearson's correlation coefficient (" $R$ ") for elements' concentration vs. depth, average ("M") and standard deviation ("S") of elements concentrations.

Some important observations may be considered:

(i) $\mathrm{Al}, \mathrm{Ca}$ and $\mathrm{Fe}$ (Fig. 2(A))

- Although high values of " $R$ " for $\mathrm{Al}$ and Fe may be observed in the wells RJ-1 (=-0.94 and -0.90$), \mathrm{RJ}-2$ $(=0.88$ and 0.84$)$ and ES- $1(=-0.53$ and 0.78$)$ and for $\mathrm{Ca}$ in the wells RJ-2 (=-0.92) and ES-2 $(=-0.75)$, the trends are not similar since some are positive and other negative.

- The average " $M$ " indicates a progressive increment in $\mathrm{Al}$ and $\mathrm{Fe}$ from south $(=55000 ; 25000)$ to north ( $=89000 ; 47000)$; the smaller values for " $S$ " in the same direction (11000 to 2500 for $\mathrm{Al} ; 7500$ to 3500 for $\mathrm{Fe}$ ) indicate smaller variation around the average with increasing concentration.

- $\mathrm{Ca}$ is the most representative element, with low concentration values near or at the KT boundary. 

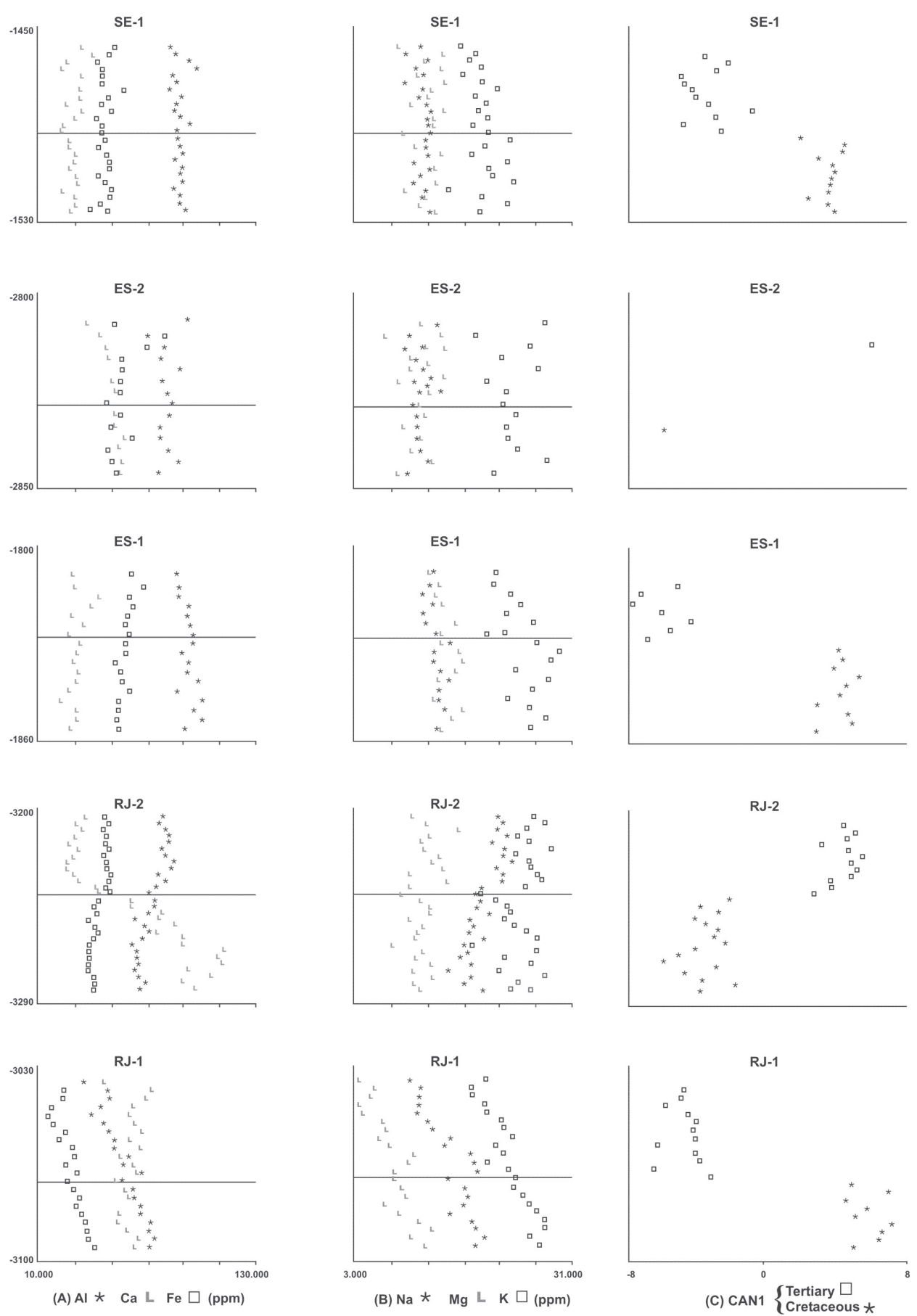

Fig. 2. Geochemical and discriminant profiles. A: Geochemical profile of the elements Al, Ca and Fe. B: Geochemical profile of the elements $\mathrm{Na}, \mathrm{Mg}$ and $\mathrm{K}$. C: Discriminant profile (canonical analysis) between Cretaceous and Tertiary Periods. Vertical axis is depth $(m)$ for all of the plots. Horizontal axis is concentration (ppm) for geochemical profiles (A, B) and canonical variable (CAN1) for discriminant profile $(C)$. Horizontal bar in geochemical profiles is the KTB.

(ii) $\mathrm{Na}, \mathrm{Mg}$ and $\mathrm{K}$ (Fig. 2(B))

- These elements present clear increment of concentration with depth in the well RJ-1. K and Na present the same tendency in the well ES-1.
- Greater values of " $S$ " in the southern region points to a general tendency of increasing dispersion in the northsouth direction (900 to 3000 for $\mathrm{Na}, 1700$ to 2700 for $\mathrm{Mg}$ and 2100 to 3000 for $\mathrm{K})$. 

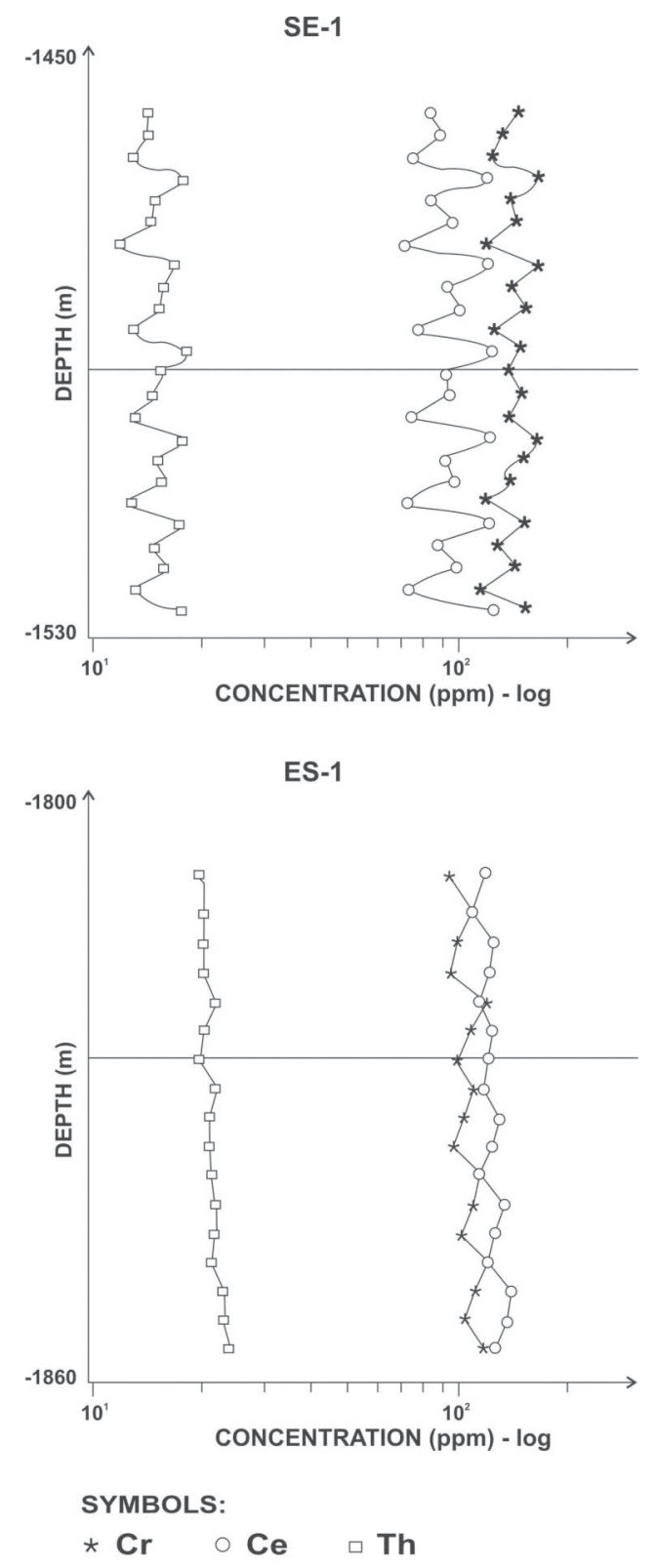

Fig. 3. Geochemical profile $(\mathrm{Cr}, \mathrm{Ce}$, Th) presenting conspicuous cyclicity. Horizontal bar in both plots is the KTB.

- The KTB is noticed by distinct concentration trends, below and above it. The most conspicuous examples are $\mathrm{Mg}$ in the well $\mathrm{RJ}-1, \mathrm{Na}$ in the wells RJ-1, and $\mathrm{RJ}-2$ and $\mathrm{K}$ in all of the wells.

(iii) $\mathrm{Cr}, \mathrm{Ce}$ and $\mathrm{Th}$ (Fig. 3)

- $\mathrm{Cr}, \mathrm{Ce}$ and Th concentrations have high values for " $R$ " (greater than 0.95) with the exception of SE-1. A concentration increase with depth is common in the well ES-1.

- Cyclicity is a remarkable aspect in almost every well and particularly in the wells SE- 1 and ES- 1 and may be related to inter-regional factors, such as Milankovitch cyclicity.

- Th is the element with a sharper discriminant aspect in the KTB.

\section{Discriminant analysis}

Of special interest it was the high discriminant capacity of chemical elements in determining the KTB profiles. Two stratigraphic units were defined: $\mathrm{K}$ (Cretaceous) and $\mathrm{T}$ (Tertiary); this number of classes determined just one canonical variable (CAN1). Some elements contribute with better discrimination: $\mathrm{K}, \mathrm{Ca}, \mathrm{Fe}, \mathrm{Cl}$ and $\mathrm{Hf}$, and, secondarily, $\mathrm{Na}, \mathrm{Al}$ and $\mathrm{Th}$. The canonical variable was composed with such elements, among others.

It is noteworthy the discrimination of the Cretaceous and Tertiary through the plot analysis (CAN1 vs. depthFig. 2(C)). The well ES-2 is an exception as it presents more variables than samples and becomes impossible a statistical analysis. The discriminating capacity is more evident when considering the high values of the Mahalanobis distance: 113.5 (RJ-1), 109.9 (ES-1), 63.4 (RJ-2) and 49.9 (SE-1).

Although the general behavior observed for the elements in the geochemical profile indicates a continuous variation across the KTB, the canonical analysis shows clear discriminant positions for the Cretaceous and the Tertiary. The action of different depositional regimes and/ or depositional conditions and/or source areas has produced different geochemical populations.

\section{Pernambuco basin and THE First DOCUMENTEd SPHERULES}

The first detailed characterization of spherules from the KTB in Brazil is derived from these occurrences in the sediments of the PE-PB Basin. This basin occurs in a narrow on-shore area of North-East Brazil, and up to now the Poty Quarry (Fig. 4) is the unique known sedimentary section in this country with outcrops spanning the KTB (Mabesoone et al., 1968; Tinoco, 1971; Stinnesbeck, 1989; Albertão, 1993, 1997; Albertão et al., 1994; Koutsoukos, 1994, 1995; Albertão and Martins Jr., 1996a, b; Marini et al., 1998, 2000).

Microspherules and shattered fragments of shocked quartz grains are common to relatively frequent in the residues from the layers near the KTB (Fig. 4) in the beds which were named C to I (Albertão, 1993; Albertão et al., 1994). Microspherules are better preserved in layer D probably because the low permeability of this bed avoided recrystallization, devitrification and weathering.

The microspherules (80-300 $\mu \mathrm{m}$ in diameter) are of similar composition, shapes, internal and surface textures as those reported from KTB clays of the North-eastern Apennines/Italy (Montanari, 1991), Caravaca/Spain 


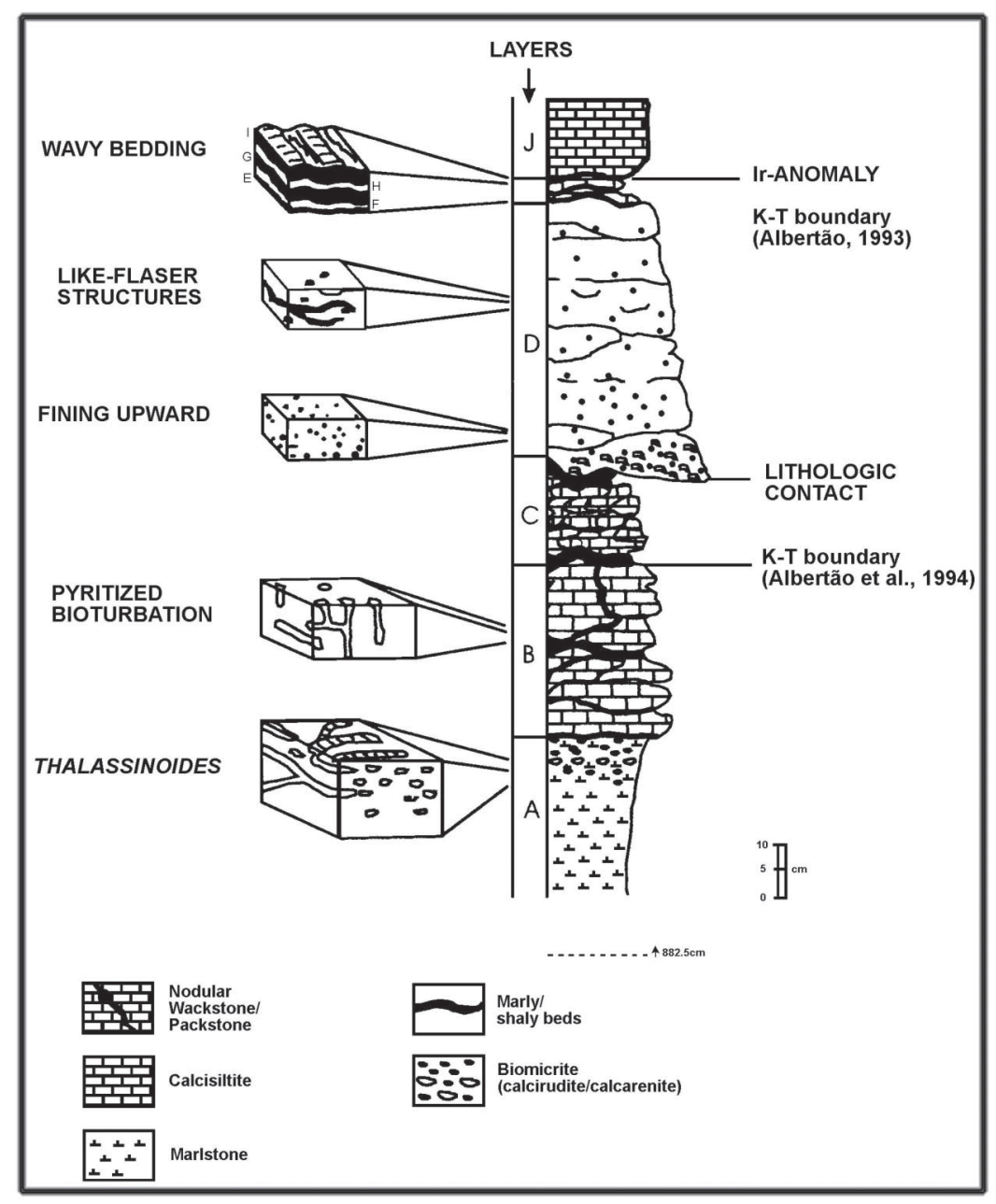

Fig. 4. Schematic section at Poty Quarry, presenting the layers A to $J$ with their main sedimentary structures. Two different possibilities for the location of the KTB are considered; the upper one coincides with the Ir-anomaly and the lower with the first occurrence of very rare Danian foramifera species. The lithologic contact defines the limit between Gramame Formation (lower sequence, Maastrichtian in age) and Maria Farinha Formation (upper sequence, Danian in age).

(Smit, 1990) and the Raton Basin/USA (Pillmore et al., 1988). Most are about $150 \mu \mathrm{m}$ across and developed primarily as spheres or, less frequently, as oblate spheroids (Figs. 5A and B); few are in the form of teardrops, with a projecting tail (Fig. 5C). Several have a surface with "crater-like" pits (Fig. 5A) and protruding mounds or protrusions (Fig. 5C) with various shapes and sizes. They vary in color from pale yellow to dark gray, and the surface from smooth (Fig. 5A) to corroded and pitted (Fig. 5B). The morphological features of the microspherules are similar to that of known tektites (McNamara, 1985) and microtektites (Wang, 1992; Claeys et al., 1992).

According to the preliminary SEM analysis described by Koutsoukos (1995), using the energy dispersive system, the typical composition (wt \%) of the outer surface of the spherules is $\mathrm{Ca}$ (41.4-44.4), $\mathrm{P}(15.4-16.3)$, $\mathrm{Fe}(0.4-$ 2.3), Mn (0.2-0.7), Ni (0.3-0.6), Mg (0-0.7), Ti (0.2-
$0.5), \mathrm{K}(0.1-0.4)$ and $\mathrm{Si}(0-0.6)$. The cores of the spherules have a wider compositional range, but are enriched in $\mathrm{Fe}$ and locally in $\mathrm{Si}$ : $\mathrm{Ca}$ (1.3-59), Fe (6-27), $\mathrm{Si}(0-20), \mathrm{P}$ (4-8.4), $\mathrm{Ni}(0-1), \mathrm{Mn}(0.1-0.4), \mathrm{Mg}(0-2), \mathrm{Ti}(0-0.3)$ and $\mathrm{K}(0.1-0.2)$.

The composition of the outer surface of spherules is similar to the main mineralogical components of the layers where they are found, which are limestone and marlstone with reworked phosphate grains characterized by microgastropods, foraminifera and abundant concentrations of small (0.4-0.7 mm long), brownish, oval fecal pellets (microcoprolites). This suggests that the composition of the outer surface of the spherules is mostly due to diagenetic alterations.

At first the microspherules randomly scattered in layers C to I (Fig. 4) were interpreted as impact-derived melt droplets, analogous to microtektites (Albertão et al., 1994; 


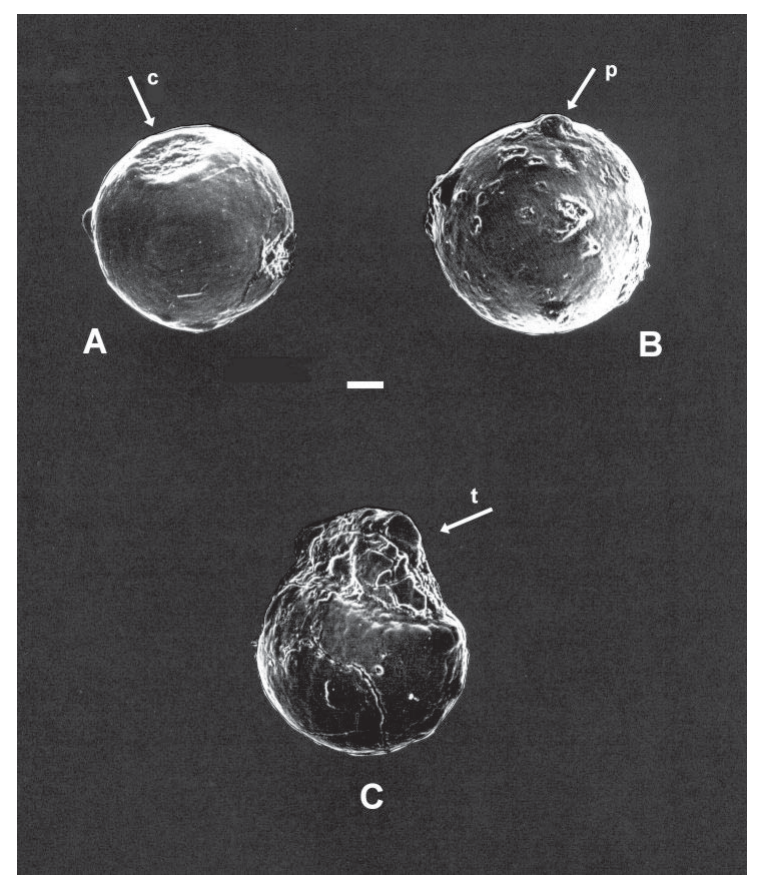

Fig. 5. Scanning electron photomicrography of three selected microspherules recovered from the Poty Quarry section (layer I). Scale bar $=20 \mu \mathrm{m}$. Microspherule (A) presents conspicuous "crater-like" pits (c), circular to irregularly shaped, and a very smooth surface. Microspherule (B) exhibits a more corroded surface with protruding mounds or protrusions $(p)$. Microspherule $(C)$ exhibits an upper portion similar to a tail $(t)$.

Albertão, 1997). Further and more accurate SEM and EPMA analysis performed on these spherules (Marini et al., 1998, 2000) have however revealed new information. At the present time, just three beds were selected for the detailed spherule analysis: E, G and I (Fig. 4). These samples were chosen due to their proximity to the KTB, and one of them (I) contains the iridium anomaly. After this study (Marini et al., 1998, 2000), a major division of these spherules into three classes was possible:

i - Brittle class

It was possible to observe that most of these spherules are fragile, consisting of thin crust of F- or Cl-rich apatite (0.5-5.0 micra) enclosing an interior aggregate of minute calcite- and/or dolomite-crystals (individual size: 0.5-3.0 micra). The internal aggregate of globular and rhomboidal crystals is loosely packed, and may form vague concentric arrangements, reminiscent of oolitic textures, indicating possible diagenetic processes involving dolomitisation of carbonate-oolites and bioclasts, and encrustation by common apatite precipitates.

ii - Resistant class

Much rarer are resistant spherules, but they do not significantly differ from the fragile ones in composition and

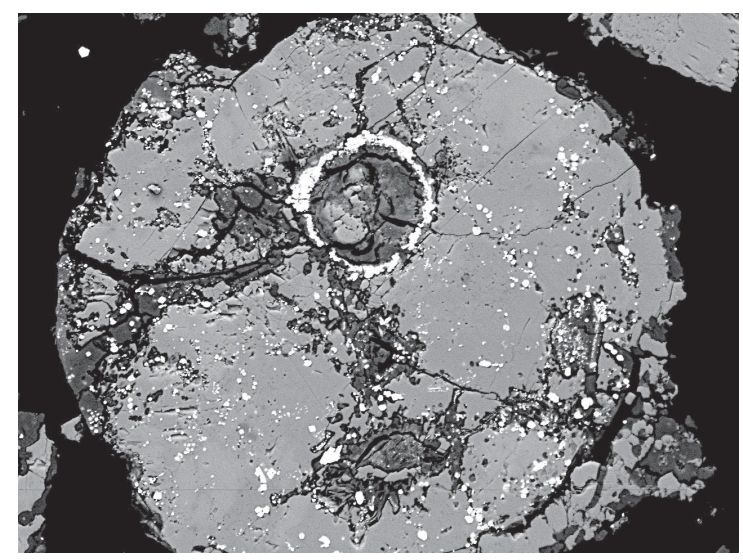

Fig. 6. Scanning electron (back-scattered) photomicrography of a microspherule recovered in the drilling core of the well RJ-3 (Campos Basin). Diameter $=1.2 \mathrm{~mm}$. Original glass is preserved near the center of the spherule (upper part of the photography).

shape. They consist of dominant, concretionary Ca- and F-rich phosphates (with low $\mathrm{Fe}$ and $\mathrm{Al}$ content). These and other minor characteristics seem to point to normal although complex diagenetic processes. Nevertheless at least in one of these resistant spherules it was possible to observe a lamellar arrangement and a relict of K-feldspar resembling sanidine; this is the unique possible indication for an impact origin.

iii - White class

These spherules found exclusively in the bed I are giant, sugared almond-spherules (sometimes reaching 0.8 $\mathrm{mm}$ ) composed mainly by fluorite with minor amounts of calcite.

In the PE-PB Basin the majority of the sampled spherules are composed mainly by F-rich apatites and strongly differ from the Al- and/or Fe-rich phosphates described elsewhere from altered KTB tektites. It is important to note that the base of bed $\mathrm{D}$, a much better candidate to contain tektite remnants, was not yet investigated for the spherule content.

In the same beds analysed for spherules, some fragments of shocked quartz grains with multiple sets of deformation lamellae also occur. The intersecting sets of straight planar lamellae were most probably formed by shock-metamorphic processes and are similar to those of shocked mineral grains found in rocks from known impact structures (Robertson and Grieve, 1977; Jansa, 1993) and from other K-T boundary sites (Bohor, 1990; Izett, 1991).

\section{NEW INVESTIGATIONS ON RJ-BASIN}

Recent studies indicate that a core from an oil well (RJ-3, Fig. 1) drilled in the 1970's in the RJ Basin recov- 


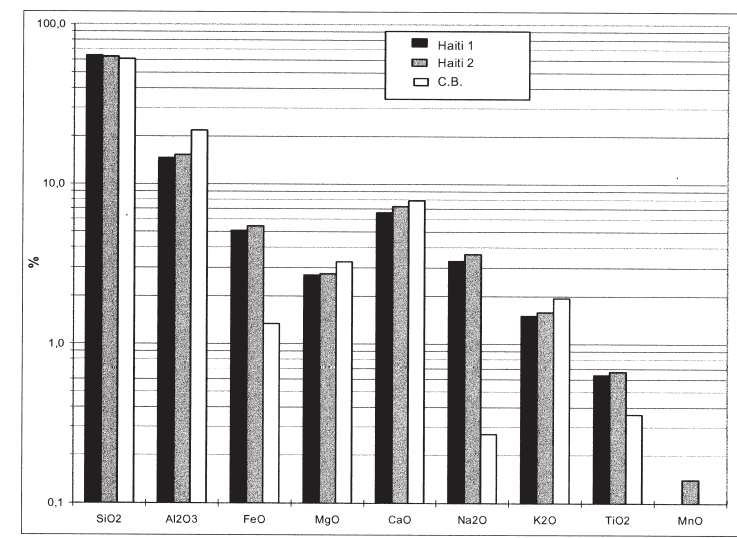

Fig. 7. Comparison between Campos (RJ-Basin) and Haiti (Beloc) tektite compositions. Chemical compositions according to Izett (1991, Haiti 1) and Sigurdsson et al. (1991, Haiti 2). $C B=$ Campos Basin.

ered an apparently continuous succession spanning the $\mathrm{KTB}$, as shown by calcareous nannofossil analysis (Grassi, 2000). It includes a 2.5-cm thick layer of spherules interpreted as tektites directly ascribed to the KTB event (Grassi and De Ros, 1999). The tektites are dark-gray to black, subspherical, about 0.3 to $1.4 \mathrm{~mm}$ of diameter (Fig. 6). They were also extensively replaced by calcite and pyrite, but several of them present internal features suggesting flow and devitrification textures of the original glass, which is preserved as minor inclusions in only a few tektites. Glass chemical composition is very similar to the tektites from Haiti as shown by microprobe analysis (Fig. 7); this is an indication that such tektites could be the most distant known record of glass and of the low angle ejecta from the Chicxulub impact structure $(\sim 7,800 \mathrm{~km})$.

\section{CONCLUSions}

1. In relation to the geochemical analysis-(i) the discriminant geochemical aspects of the KTB are not easily perceptible with a simple profiling analysis; (ii) cyclicity is a noteworthy aspect for all the elements in each well, without exception and it can be better demonstrated with logarithmic function; (iii) local factors are very important and can explain the intensive local variations, but cyclicity is indicative of inter-regional common factors in depositional processes; (iv) the canonical analysis showed the clear discriminant behavior of chemical elements across the KTB.

2. In relation to the microspherules found in the sediments near the KTB of Pernambuco Basin-(i) morphological and external characteristics are similar to tektites described elsewhere near KTB's; (ii) internal tex- ture and composition do not show direct evidence of impact origin for such spherules.

3. For the microspherules found in the well RJ-3 (Campos Basin) - the composition, internal structure and texture indicate a very probable impact origin, i.e., they are probably tektites.

\section{REFERENCES}

Albertão, G. A. (1993) Abordagem interdisciplinar e epistemológica sobre as evidências do limite CretáceoTerciário, com base em leituras efetuadas no registro sedimentar das Bacias da Costa Leste Brasileira. M.Sc. dissertation, Federal University of Ouro Preto, Ouro Preto, Minas Gerais State, Brazil. 2 volumes, $251 \mathrm{pp}$.

Albertão, G. A. (1997) The Cretaceous-Tertiary Boundary in Brazil-state of the art and peculiarities. Sphaerula (International Journal of IGCP Project 384-Impact and Extraterrestrial Spherules) 1(1), 101-114.

Albertão, G. A. and Martins, P. P., Jr. (1996a) La séquence stratigraphique et géochimique de la limite CrétacéeTertiaire dans le bassin de Pernambuco/Paraíba au Nordest de Brésil. Géologie de L'Afrique et de L'Atlantique Sud (12e. Colloque Africain de Micropaléontologie et $2 e$. Colloque de Stratigraphie et Paléogéographie de L'Atlantique Sud). Elf-Aquitaine Édition (Jardiné, S., Klasz, I. and Debenay, J.-P., eds.), Pau, France. Mémoire 16, 403411.

Albertão, G. A. and Martins, P. P., Jr. (1996b) A possible tsunami deposit at the Cretaceous-Tertiary Boundary in Pernambuco, Northeastern Brazil. Sed. Geol. 104(1-4), 189-201.

Albertão, G. A. and Martins, P. P., Jr. (1996c) Geochemical aspects of the South Atlantic Western Margin in Brazil. SAMC News (IGCP Project 381-South Atlantic Mesozoic Correlations), 38-39.

Albertão, G. A., Koutsoukos, E. A. M., Regali, M. S. P., Attrep, M., Jr. and Martins, P. P., Jr. (1994) The CretaceousTertiary boundary in southern low-latitude regions: preliminary study in Pernambuco, Northeastern Brazil. Terra Nova 6(4), 366-375.

Bohor, B. F. (1990) Shock-induced microdeformations in quartz and other mineralogical indications of an impact event at the Cretaceous-Tertiary boundary. Tectonophysics 171(14), 359-372.

Claeys, P., Casier, J.-G. and Margolis, S. V. (1992) Microtektites and mass extinctions: evidence for a Late Devonian asteroid impact. Science 257, 1102-1104.

Delício, M. P., Oliveira, A. D., Albertão, G. A. and Martins, P. P., Jr. (1998) Looking for spherules at the CretaceousTertiary (K-T) boundary in Pernambuco/Paraíba Basin, NE Brazil. 1998 Annual Meeting of IGCP 384, Extraits (Detre, C. H. and Toth, I., eds.), 28, Budapest.

Grassi, A. A. (2000) O limite Cretáceo-Terciário das Bacias de Pernambuco-Paraíba e Campos: um estudo multidisciplinar com ênfase na bioestratigrafia de nanofósseis calcários. Unpublished M.Sc. dissertation, Federal University of Rio Grande do Sul, Porto Alegre, Rio Grande do Sul State, 
Brazil. 238 pp.

Grassi, A. A. and de Ros, L. F. (1999) Tectitos atribuídos ao ejeto de baixo ângulo de Chicxulub no limite CretáceoTerciário da Bacia de Campos, Brasil. Bol. $5^{\circ}$ Simpósio sobre o Cretáceo do Brasil, 681-686, Rio Claro, São Paulo.

Izett, G. A. (1991) Tektites in Cretaceous-Tertiary boundary rocks on Haiti and their bearing on the Alvarez impact extinction hypothesis. J. Geophys. Res. 96(E4), 20879-20905.

Jansa, L. B. (1993) Cometary impacts into ocean: their recognition and the threshold constraint for biological extinctions. Palaeogeogr., Palaeoclim., Palaeoecol. 104, 271-286.

Koutsoukos, E. A. M. (1994) The Cretaceous-Tertiary boundary in Pernambuco, Northeastern Brazil. 2nd. Colloquium of Stratigraphy and Paleogeography of the South Atlantic, Angers, 81-82 (abstr.).

Koutsoukos, E. A. M. (1995) The Cretaceous-Tertiary boundary in southern low-latitude regions: preliminary study in Pernambuco, northeastern Brazil-Comments and Reply. Terra Nova 7, 375-382.

Mabesoone, J. M., Tinoco, I. M. and Coutinho, P. N. (1968) The Mesozoic-Tertiary boundary in Northeastern Brazil. Palaeogeogr., Palaeoclim., Palaeoecol. 4, 161-185.

Marini, F., Albertão, G. A., Oliveira, A. D. and Delício, M. P. (1998) Preliminary SEM and EPMA investigations on KTB spherules from the Pernambuco area (NE Brazil). 1998 Annual Meeting of IGCP 384, Extraits (Detre, C. H. and Toth, I., eds.), 61-62, Budapest.

Marini, F., Albertão, G. A., Oliveira, A. D. and Delício, M. P. (2000) Preliminary SEM and EPMA investigations on KTB spherules from the Pernambuco area (Northeastern Brazil): diagenetic Apatite and Fluorite concretions, suspected Fluorine anomalies. Proceedings of the 1998 Annual Meeting
TECOS (Detre, C. H., ed.), 109-117, Akadémiai Kiadó, Budapest.

McNamara, K. (1985) Tektites. 10-17. Western Australian Museum, Perth.

Montanari, A. (1991) Authigenesis of impact spheroids in the $\mathrm{K} / \mathrm{T}$ boundary clay from Italy: new constraints for high resolution stratigraphy of terminal Cretaceous events. J. Sedim. Petrol. 61(3), 315-339.

Pillmore, C. L., Fleming, R. F. and Nichols, D. J. (1988) Field guide to the continental K-T boundary in the Raton Basin, Colorado and New Mexico. 3rd. International IGCP-IPA Conference on Global Bio-events (16-17 May 1988), 44 pp.

Robertson, P. B. and Grieve, R. A. F. (1977) Shock attenuation at terrestrial impact structures. Impact and Explosion Cratering (Roddy, D. J., Pepin, R. O. and Merril, R. B., eds.), 687-702, Pergamon Press, New York.

Sigurdsson, H., D’Hondt, S., Arthur, M. A., Zachos, J. C., Van Fossen, M. and Channel, J. E. T. (1991) Glass from the Cretaceous/Tertiary boundary in Haiti. Nature 349(6309), 482487.

Smit, J. (1990) Meteorite impact, extinctions and the Cretaceous-Tertiary boundary. Geol. Mijnb 69, 187-204.

Stinnesbeck, W. (1989) Fauna y microflora en el límite Cretácico-Terciario en el Estado de Pernambuco, noreste de Brasil. Contribuciones de los Simposios sobre el Cretácico de América Latina, Parte A: Eventos y Registro Sedimentario, 214-230.

Tinoco, I. M. (1971) Foraminíferos e a passagem entre o Cretáceo e o Terciário em Pernambuco. Doctoral Thesis, Univ. of São Paulo, Brazil, 132 pp.

Wang, K. (1992) Glassy microsherules (microtektites) from an Upper Devonian limestone. Science 256, 1547-1550. 